\title{
AMULETS DEPICTING THE EYE OF HORUS FROM BURIAL MOUNDS OF EARLY NOMADS IN THE SOUTHERN URALS
}

\author{
Olga V. Anikeeva \\ State Research Institute for Restoration, Moscow, Russian Federation
}

\author{
Leonid T. Yablonsky
}

Institute of Archaeology, Russian Academy of Sciences, Moscow, Russian Federation

\begin{abstract}
Three faience amulets depicting the Eye of Horus (Wedjat) were discovered in the Southern Urals. They all come from burial mounds of early nomads and are dated by local chronologies to the $5^{\text {th }}-4^{\text {th }}$ centuries BC. One pendant comes from a pristine (not looted) burial of the burial mound Filippovka I; it was found in a complex of objects covered with a mirror. The two other pendants, similar to one another, were found in looted burials of the burial mound Novy Kumak. The material and iconography of the Filippovka amulet place it close to the types $138 \mathrm{v}, \mathrm{w}$, and $\mathrm{z}$ in the classification of F. Petrie, who believed that this type of depiction of the Eye of Horus had originated from the time of the $6^{\text {th }}$ Dynasty (end of the Old Kingdom) and persisted through the end of the Ptolemaic Egypt. The pendants from Novy Kumak are comparable to Petrie's types $138 \mathrm{r}$, s, and t, which appear during the $23^{\text {rd }}$ Dynasty $\left(3^{\text {rd }}\right.$ Intermediate Period) and vanish early during the Ptolemaic dynasty. An extensive import of goods from Egypt to Mediterranean countries during the $1^{\text {st }}$ millennium BC resulted in the local craft centers in Syria, Judea, Anatolia, Greece, Italy and island states copying the Egyptian technologies of manufacturing glass and faience and starting manufacture of their own goods with the imported technologies. Trace analysis and analysis of faience composition showed that the pendants from Filippovka and Novy Kumak had been manufactured following different Egyptian faience recipes. SEM and SEM/EDX analyses of the Filippovka pendant suggest a possibility that it was made in handicraft centers of the Eastern Mediterranean with a borrowed technology.

L. T. Yablonsky has developed the original idea of the research, aimed at not only revealing the origin of imported items, but also identifying the purpose of these amulets in rituals of early nomads. The author has analyzed the semantics of the amulets' image adopted in ancient Egypt, and the likely use of these amulets by nomads, made conclusions. O. V. Anikeeva has studied the iconography of amulets, their distribution among nomads, investigated the materials using natural-science methods.

Key words: early nomads, Southern Urals, Wedjat, the Eye of Horus, Egyptian faience, production technology, chronology, origin.

Citation. Anikeeva O.V., Yablonsky L.T. Amulets Depicting the Eye of Horus from Burial Mounds of Early Nomads in the Southern Urals. Vestnik Volgogradskogo gosudarstvennogo universiteta. Seriya 4, Istoriya. Regionovedenie. Mezhdunarodnye otnosheniya [Science Journal of Volgograd State University. History. Area Studies. International Relations], 2018, vol. 23, no. 3, pp. 63-81. (in Russian). DOI: https://doi.org/10.15688/jvolsu4.2018.3.6

\section{АМУЛЕТЫ «ГЛАЗ ХОРА» ИЗ КУРГАНОВ РАННИХ КОЧЕВНИКОВ НА ЮЖНОМ УРАЛЕ}

\section{Ольга Викторовна Аникеева}

Государственный научно-исследовательский институт реставрации, г. Москва, Российская Федерация

$$
\text { Леонид Теодорович Яблонский }
$$

Институт археологии РАН, г. Москва, Российская Федерация 
Аннотация. На Южном Урале три фаянсовых амулета в форме глаза Хора происходят из курганных захоронений ранних кочевников (могильники Филипповка 1 и Новый Кумак) и датируются по местным хронологическим шкалам V-IV вв. до н. э. Анализ иконографии филипповского амулета показывает, что подобная форма изображения оформляется в фаянсе к концу Нового царства и широко распространяется в Египте в Позднем - Эллинистическом периодах. Датированные аналоги новокумакским амулетам по форме (но из камня) появляются в Египте в I Переходный период, характерный облик в фаянсе формируется в период Нового царства, трансформируется и постепенно исчезает в Эллинистический и Римский периоды. В I тыс. до н. э. широкое распространение египетского импорта в Средиземноморье приводит к тому, что ремесленные центры в районах сосредоточения торговли (Сирия, Иудея, Анатолия, Греция, Италия и островные государства) копируют египетские технологии и начинают производство собственных товаров. Трасологический анализ, изучение состава фаянса показали, что филипповская и новокумакские подвески произведены по различным рецептам изготовления египетского фаянса, но, судя по близости контуров формы и пропорций, могли изготавливаться в одном ремесленном центре. Анализ структуры фаянса филипповской подвески методами РЭМ и РСМА не исключает вероятности ее производства в ремесленных центрах Восточного Средиземноморья по заимствованной технологии.

Л.Т. Яблонскому принадлежит оригинальная идея работы, целью которой является не только установление происхождения импортных предметов, но и выявление назначения данных амулетов в ритуалах ранних кочевников. Для этого им проанализирована семантика образа амулетов, принятая в Древнем Египте, а также вероятное использование этих амулетов кочевниками, подготовлены выводы. О.В. Аникеевой написаны разделы по иконографии амулетов, распространению и путям поступления их к кочевникам, проведено изучение материала естественнонаучными методами.

Ключевые слова: ранние сарматы, Южное Приуралье, Уаджет, Глаз Хора, египетский фаянс, техника изготовления, хронология, происхождение.

Цитирование. Аникеева О. В., Яблонский Л. Т. Амулеты «Глаз Хора» из курганов ранних кочевников на Южном Урале // Вестник Волгоградского государственного университета. Серия 4, История. Регионоведение. Международные отношения. - 2018. - Т. 23, № 3. - С. 63-81. - DOI: https://doi.org/10.15688/jvolsu4.2018.3.6

Введение. На Южном Урале известны три подвески в виде глаза Хора. Все они происходят из курганных захоронений ранних кочевников. Две совершенно идентичные подвески найдены в Ново-Кумакском могильнике, расположенном в 8 км к востоку от г. Орска, в ограбленных погребениях 2 и 4 кургана 26. Погребения датированы концом VI первой половиной $\mathrm{V}$ в. до н. э., археологический контекст находок не определяется [3, c. 36-37]. Третья подвеска обнаружена при доследовании кургана 1 могильника Филипповка 1 [11, с. 221-224] в выявленном неграбленом женском захоронении (погребение 2) [6; $12 ; 13]$. Исключительно разнообразный и богатый инвентарь располагался вокруг тела погребенной, как отдельными закрытыми комплексами, так и штучно. Археологическими находками погребение датируется IV в. до н. э. $[6$, с. $76 ; 12$, с. 106$]$.

2. Археологический контекст подвески из Филипповского кургана. Основу одного из комплексов погребения 2 составляло серебряное зеркало. Под диском зеркала лежали: серебряный туалетный сосудик, костяная и бронзовая ложечки, кремневый и бронзовый трехлопастной втульчатый наконечники стрел, сложносоставной предмет в виде стержня из бирюзы, пасты и золота, разнообразные бусы, подвески и пронизи, инструменты для выделывания каменных бус, полуобработанные заготовки каменных бус, фрагменты золотых украшений, округлые ритуальные предметы из минеральной крошки, пигменты в кожаных мешочках. Амулет Уаджет был положен отдельно вместе с несверленым цилиндром из индийского сарда. Под рукояткой находился большой прямоугольный оселок, а под ним лежали шесть золотых татуировальных игл и три железных ножа, инкрустированных золотом.

В отечественной археологии давно была отмечена особая роль зеркала в погребальном обряде древних народов Волго-Уральского региона. У сарматов и некоторых народов Средней Азии оно обладало особыми магическими свойствами, а разбитое зеркало (и его осколки) ассоциировалось со смертью хозяйки [1; 9, с. 90-94; 10].

Все предметы под зеркалом можно разделить на две группы: производственного и культового назначения. Исходя из положения 
и окружения, подвеска в форме глаза Хора, безусловно, является амулетом и относится ко второй группе.

\section{3. Форма и иконография амулетов.}

3.1. Амулет из Филипповки 1 сделан в форме подвески (рис. 1, 1, 2) с размерами: длина - 20 мм, высота - 15 мм, ширина 6 мм. Отверстие для подвешивания просверлено в прямоугольном валике, расположенном на верхней боковой грани. Внешние плоскости валика имеют поперечный линейный рисунок. Размеры валика $4 \times 3 \times 6$ мм, диаметр отверстия - 1,8 мм.

Подвеска имеет симметричные двусторонние изображения, так называемое «мерти» [7, с. 43]. Передняя и нижняя боковые поверхности - рельефные, задняя боковая грань плоская гладкая. В центре каждой композиции в фас под углом расположен человеческий глаз с круглым зрачком. Сверху глаз венчается двумя валиками. На нижнем, гладком, с одного края есть три наклонные насечки. Верхний валик украшен елочным орнаментом и обозначает надбровную дугу. Внизу под глазом в рельефе выделен удлиненный уступ с вертикальными бороздками. По мнению египтологов $[14$, p. 86], этот выступ и отходящая рядом в нижний угол двойная линия, на конце завершающаяся спиралью, означают стилизованное изображение щеки сокола и в данной совокупности характерных деталей являются изображением глаза египетского бога Хора.

Наиболее полная коллекция древнеегипетских амулетов с двусторонним изображением ока Хора собрана и изучена В.Ф. Питри [41, pls. XXIV-XXV]. Исходя из материала, размеров и иконографии, филипповская подвеска наиболее близка типам 138 v, w, z по классификации В.Ф. Петри, который считал, что в фаянсе подобный тип изображения ока Хора появляется в VI династии фараонов Древнего царства (XXIV-XXIII вв. до н. э.) и существует до конца птолемеевского Египта [35, p. 32-33, pl. XXV, 38v; 40, p. 329, 351].

За последние 30-35 лет опубликовано много новых данных по составу и рецептам изготовления различных типов фаянса, что позволило изменить и уточнить время появления определенных форм фаянсовых изделий. Поэтому хронология фаянсовых амуле- тов, данная В.Ф. Питри, нуждается в уточнении. Очевидно, образ глаза Хора, представленный на амулете из Филипповки, складывается не позднее конца III - начала II тыс. до н. э. ${ }^{1}$ Серийное производство египетских фаянсовых фигурных и рельефных объектов отмечается со времени правления XVIII династии Нового царства (то есть не ранее XVI-XIII вв. до н. э.) ${ }^{2}$ и продолжается до Эллинистического периода [32, p. 26; 34, p. 2, 8-10; 43, p. 22, 27]. Известно, что двусторонние фаянсовые амулеты с характерной для филипповского амулета иконографией глаза широко были распространены в Египте в VIIIV вв. до н. э. (рис. 2, 1-14) и происходят из раскопок Таниса и Навкратиса (В.Ф. Питри, 1884-1885 гг.). Сейчас на сайте Бостонского музея ${ }^{3}$ опубликовано свыше 40 фаянсовых амулетов «Глаза Хора» с современными датировками по археологическому материалу, иконография 28 из них соответствует амулету из Филипповки 1 . На рисунке $2,1-13,16$ представлены характерные типы, отличающиеся соотношениями в пропорциях и степенью детализации основных элементов. Часть из них датирована 688-332 гг. до н. э. (рис. 2, 1-5), датировка других (рис. 2, 613) сужена до 380-332 гг. до н. э. В амулетах первой группы продольное сквозное отверстие сделано под надбровной дугой. Во второй группе распространяется тип амулета с отверстием в валике, расположенном в центре верхней боковой грани (рис. 2, 6, 12, 13). Поверхность всех валиков декорирована поперечными линиями. Наличие аналогичного валика на подвеске из Филипповки позволяет предположить, что он был изготовлен в пределах 380-332 гг. до н. э.

Практически на всех египетских амулетах фиксируется продольно-горизонтальное расположение глаза и отчетливо треугольная форма удлиненного выступа под ним. Отношение длины к высоте амулетов с отверстиями в верхних валиках не превышает 1,18 (рис. 2, 6, 12, 13). Амулет из Филипповки отличается отчетливо выраженным наклоном глаза вниз, что приводит к уменьшению общей высоты амулета и увеличению отношения длины к высоте до 1,34. Поэтому продольный разрез филипповского амулета (рис. $1,1 a$ ) отличается от форм продольных 
разрезов египетских амулетов (рис. 2, 1-14). Это позволяет предположить, что для его изготовления использовалась другая форма отливки, чем для традиционных египетских амулетов.

Найти аналоги такой формы среди египетских фаянсовых амулетов в коллекциях других музеев и частных коллекциях нам не удалось. В коллекции музея искусств Метрополитен есть два египетских литых золотых амулета в форме глаза: левый относится к Эллинистическому периоду, правый - к Позднему периоду, охватывающему оба завоевания Египта персами (рис. 3). В декорации правого амулета отмечаются характерные для иранской ювелирной школы лепестковые штампованные розетки и орнамент поверхности разнообразными треугольниками и линиями мелких шариков зерни. Угол наклона глаза и линии оформления век полностью идентичны этим элементам филипповского амулета. Декорирование левого амулета иное и намного более аскетичное, положение глаза горизонтально и соответствует его расположению на фаянсовых египетских амулетах. Вполне вероятно, что характерный наклон глаза в амулетах этой формы появляется под влиянием персидских традиций.

3.2. Амулеты из Нового Кумака. Подвески имеют плоскую форму и общие размеры: длина - 11,5 мм, высота - 8,5 мм, ширина - 3 мм (рис. $1,3 a, 3 b$ ). Продольное отверстие расположено в средней части амулетов, его диаметр - 1,5 мм. Для этих амулетов характерно одностороннее (правое) изображение глаза Хора, надбровная дуга и глаз на которых выделены рельефно выступающей черной глазурью.

Исходя из размеров (малые), материала (фаянс) и характера декора, эти подвески наиболее близки типам 138 r, s, t по классификации Ф. Питри, который предполагал, что в фаянсе подобный тип изображения Уаджет появляется во время правления XXIII династии фараонов и исчезает в начале птолемеевского времени [35, p. 32-33, pl. XXV, 38 r, s, t]. Найденные близкие аналоги среди египетских амулетов этой формы (рис. 2, 15, 17-23) показывают, что, вероятно, эта форма амулета зародилась раньше - в I Переходный период ${ }^{4}$. Ее характерный облик (рис. 2, 21,
22) формируется в период Нового царства, существует до Позднего периода (рис. 2, 19, 20) и плавно исчезает в Эллинистический период (рис. 2, 23).

4. Распространение и пути поступления амулетов. Б.Б. Пиотровский считал, что египетские амулеты до середины VII в. до н. э. появлялись в Восточном Средиземноморье благодаря финикийским торговцам основным посредникам в торговле Египта и Передней Азии. Важную роль играла «царская дорога», проходившая от Эфеса на Сарды и Сузы через Малую Азию, Армению и Ассирию [5, с. 22]. Далее они распространялись в Закавказье 5 , Центральный Иран и попадали в Среднюю Азию. C VI в. в торговых связях Средиземноморья с Ахеменидским Ираном возрастает посредническая роль греческих поселений: Навкратиса в Египте, Милеса и Родоса в Малой Азии.

В раннем железном веке в Средиземноморье наиболее широко представлены амулеты двух типов: мемфисская триада СекметНефертем-Птах и Уаджет (Глаз Хора). В первой половине VII в. появление амулетов Уаджет связано с торговой деятельностью южнофиникийких городов, и они распространены на Сицилии, Сардинии, восточном побережье Испании и северном побережье Туниса [24, p. $52-$ $58,65,66$, fig. 2, 3, tab. 1]. Распад греко-северофиникийского союза, связанный с разрушением Сидона в 677 г., а также возрастание во второй половине VII в. в Малой Азии роли Ассирии приводит к возвышению южнофинийских городов (Тира), в торговые сферы влияния которых, кроме Египта и Аравии, попадает Левантийское побережье, Сирия и Лидия [24, p. 60 , $62,65,66]$. И со второй половины VII в. амулеты Уаджет распространяются в Малой Азии и на Левантийском побережье.

Находки амулетов-подвесок в форме глаза Хора, отдатированных авторами раскопок или исследователями ахеменидским временем, известны по раскопкам городища Yoqne'am II (Израиль) [16, p. 389, № 19], в Сузах [18, p. 8, 42; 39, S. 197, Abb. 79 E. 59], Нимруде (Ирак) [18, Р. 8-9], Хорсабаде (Северный Иран) [18, p. 11], Ашшуре (Ирак), Дейлемене (Иран) [48, p. 94, fig. 3], на Алтин-Тепе (Восточная Турция) [18, p. 14], Динкха-Тепе (Северо-Западный Иран) [33, p. 65, fig. 36, 64]. 
В Причерноморье среди египетских амулетов преобладают скарабеи, известна единственная находка фаянсового амулета Уаджет из погребения VI в. до н. э. в Констанце (Румыния) [28, р. 131]. Единичные амулеты Уаджет найдены в Керчи в слоях III-II вв. до н. э. и лишь в римское время распространяются вглубь страны [5, с. 20, 24-26, fig. 2].

Анализ ареалов распространения амулетов Уаджет в середине I тыс. до н. э. показал, что они поступали на Южный Урал с территории ахеменидской державы. Иконография большинства амулетов в форме глаза Хора с территории Восточного Средиземноморья и Древнего Ирана близка амулету из Филипповки, большинство экземпляров найдено именно в погребениях. Аналоги амулетам из Нового Кумака нами не обнаружены.

5. Семантика образа. В многочисленных версиях и вариантах текстов о Глазе Хора, Уаджет, Оке Ра или Атума, относящихся к разным периодам истории Древнего Египта, присутствует мотив утраты и последующего обретения богом его глаза, осмысленного как установление гармонии, порядка, истины, благоденствия. Формой образа в жертвоприношениях и ритуалах служили изображения Ока Хора (синоним - Уаджет) на саркофагах, стенах гробниц, стелах. Подвески-амулеты из металла, камня и фаянса вставлялись в прорези на личинах статуй, масок и антропоморфных гробов, клались на голову или в одежды мумий в гробницах и захоронениях. Из всех вотивных объектов Глаз Хора, являясь одним из древних и могущественных, остается наиболее сложным, поддающимся лишь приблизительной дифференциации образов древнеегипетской мифологии [17, p. 3], вероятно, потому, что упоминание Глаза Хора переплетено с именами многих божеств и затруднительно выделить его характеристики в текстах дошедших до нас сказаний и легенд [26, p. 182].

Для архаических мифов и легенд, ранних текстов Пирамид и Саркофагов характерна общая тема о разгорающейся ярости божественного Ока на рассвете времен как всеобъемлющем шторме, который приводил к самому краю гибели или угасания человечества. Глаз Хора сравнивается с небесным «пламенем», падающим с неба, несущим огонь и опустошение [15, S. 19-21; 20, p. 98, 100, 162, 264;
26, p. $182-193 ; 37$, p. $289 ; 22$, p. 227, 319, 506; 23, p. $98,100,162,264 ; 47$, p. 4$]$.

Д.Г. Грифитс, занимавшийся различием в трактовке смысла Уаджет, Глаза Хора и Глаза Ра, полагает, что Уаджет, трансформированный в око Хора, а позднее в око Ра, обозначает здоровый, а не поврежденный глаз Хора. Он считает, что в текстах Пирамид происходит переплетение и взаимосмешение двух мифологических тем о божественном Оке. Первая тема говорит о поединке двух богов, Хора и Сета [27, p. 124, 226]. Сет вырывает левый глаз Хора, а бог Тот исцеляет поврежденный глаз и возвращает его Хору. Хор использовал возрожденный глаз для воскрешения своего отца Осириса. Вторая тема связана с Богиней странствующего Ока, неистовство которой является причиной катастроф, а успокоение несет благоденствие и восстанавливает порядок в мире. Понятие Уаджет четко связывалось со странствующим Оком и отделялось от поврежденного Глаза Хора. Возникает представление о солнечной природе этого глаза и его идентификации с глазом Ра, хотя в то же время он является неповрежденным глазом Хора. В текстах птолемеевского периода отчетливо прослеживаются две роли Хора: первоначальная роль Хора - врага Сета и последующая роль Хора, идентифицирующегося с богом Солнца, равного Ра. В первом случае под глазом Хора подразумевается поврежденный глаз, во втором случае - два глаза бога Солнца, связанные с утренней и вечерней лодками Солнца [26, p. 182, 183, 185, 189].

Этот символ является как частью - оком божества, так и самостоятельным божеством, обычно женского рода. Многие богини ассоциировались с Глазом Гора: Уаджет, Хатор, Изис, Мут, Сакмет. Часть исследователей считают, что это глаза сокологолового бога Хора - Уаджет, другие ставят вместо Хора бога Солнца $\mathrm{Pa}$, третьи оспаривают, что это глаза египетского бога солнца Ра. Большинство ученых полагают, что символ глаза - это окно, через которое божество (дух) видит все, причем правый глаз представляет Солнце, левый - соответственно Луну [30, p. 14].

В папирусе Бремнера-Ринда богиня Сакмет защищает фараона и поражает его врагов: «Огонь Глаза посылает силу огненным 
языкам именем Уаджет, Око истребляет тебя как Поглощающее Пламя, оно властвует над тобой именем Сакмет, его огненная стена против тебя как Побеждающая Змея» [19, p. 45]. Сакмет в образе яростного Ока Хора многократно упоминается в сакральных текстах Фил: «Сакмет, сильная, когда она принимает форму оживляющего Глаза, но распространяющего огонь, когда она идет, окруженная пламенем и опаляет мятежников жаром своих губ...» [18, p. 4].

Основной сюжет в теме Блуждающей Богини (обычно отождествляется с Хатор, Уаджет, Мут, Тефнут) заключается в изгнании богини в удаленные земли (Нубию или Ливию), где она продолжала разрушительные неистовства и принимала обличие рассвирепевшего Ока или льва [18, p. 4]. Богиня Неистового Ока успокаивалась от ужасающей ярости в результате героического или магического вмешательства богов Шу, Онуриса или Тота и возвращалась в Египет, что спасало мир от полного вымирания [20, p. 36, 155, 278; 21$, p. $45 ; 22$, p. $36,155,378]$.

Миф о блуждающей богине в форме неистового Ока присутствует в различных новогодних ритуальных празднествах, проводимых по всему Египту в птолемеевский период [18, p. 6]. Они включают ритуальные танцы, экзальтированные пляски под громкую музыку, возлияния и факельные шествия. Неистовые шумные действия призваны успокоить неистовство Ока, смягчить богиню, отвращая вред и гибель. Умиротворение Ока, воцарение его в центре короны в виде кобры символизирует укрепление верховной власти, восстанавливающей порядок в мире [29, р. 6].

Уаджет была именем символа, также называемого Глазом Хора, Глазом Хатор, Оком Ра, в зависимости от времени появления символа, и существовала задолго до утверждения этого культа. Она являлась верховной богиней уже в Древнем царстве и изображалась в виде вертикально стоящей кобры, являясь символом верховной власти. Символ украшал центральную часть короны фараона и выражал законность правителя [42, p. 34]. Затем кобра ассоциируется с правителем и царством Нижнего Египта и становится эмблемой Нижнего Египта. Во время объединения Египта на короне фараонов образ Нехбет
(Нехебт), изображаемой в виде белого орла или грифа, объединяется с образом Уаджет. В символику короны вводится образ солнца и других божеств. Огненный глаз бога Солнца Ра представлен солнечным диском, который защищают две вертикально стоящие кобры и крылья [42, p. 35-36].

Одновременно с этим символ Уаджет изображался в египетской иконографии как сильно стилизованный человеческий глаз с элементами, обозначающими отметки на голове сокола $[14$, p. 86,98 , pl. 99 b, с ]. Хор - древнеегипетский бог Неба, он изображался в виде сокола или человека с головой сокола. Символ связывается с образом матери Хора, богини Хатор, и других божеств, связанных с ней. В Среднем царстве изображение глаза широко распространяется на саркофагах, стелах, в посмертных надписях захоронений, являясь амулетом и предметом украшений $[18$, p. 8].

Возникал вопрос: термин «Уаджет» первоначально относился к Глазу Хора или Ра? В ранних текстах Пирамид термин использовался несколько раз как эпитет Глаза Хора и никогда не применялся для обозначения бога $\mathrm{Pa}$ [26, p. 191]. Существует мнение, что доктрину о двух глазах Хора ввели гелиопольские жрецы [26, p. 192]: до них легенда о поединке Хора и Сета и борьбе за определенные части тела (Хор вырвал у Сета тестикулы, Сет - левый глаз Хора) не имела астрального подтекста, захваченные части тела являлись символами власти или верховной власти. Упоминание о втором - здоровом, неповрежденном глазе, который находится в Heliopolis, появляется во времена Нового царства. Этот глаз означает Солнце, и в то же время он же есть неповрежденный здоровый глаз Хора. Появляется новый бог-сокол Khenty-ierty, который имеет два глаза [26, р. 190-192]. Исходя из текстов Пирамид, более вероятна трактовка двух глаз Хора как заходящего и восходящего солнца, так как упоминаний о Солнце и Луне там еще нет [26, p. 190]. Причем по верованиям Среднего царства смертный фараон подобен Хору в жизни и Осирису в смерти. Это связано с мифами Среднего царства о том, что Хор после восхождения на трон отдает свой левый глаз Исиде для воскрешения своего отца Осириса. Таким образом, Уаджет символизирует воскрешение после жизни и 
связывается с культом Осириса, так же как и с культом Хора. Этим определяется контекст амулета в загробной жизни как воскрешение или возрождение после смерти $[18$, p. 10]. В текстах птолемеевского периода образы Хора и Уаджет тесно переплетаются и идентифицируются с великим богом Неба, чьими глазами являются Солнце и Луна [26, р. 190, 191]. Б.Б. Пиотровский считал, что оба амулета-глаза позволяют составить цепочку символов: Глаз (Гор спасает Осириса, Лунный глаз) Солнце (Ра-творец, Солнечный глаз) - и оба они дают и защищают жизнь $[4$, c. 10,12$]$.

Таким образом, один глаз Хора (синоним Уаджет) возникает как символ божественного (небесного) ока, отражавший сложные мифотворческие представления о божественной природе социального лидера - фараона, его власти, которая объединяет Египет, отождествляется с защитой миропорядка, отсутствием катастроф и хаоса. С другой стороны, в этом символе с самого начала сильны мотивы жертвоприношения и посмертного воскресения («оживления» воплощения, возвращение души погребаемому телу). Ритуальная практика Глаза Хора, отражая идею о целостности космоса, связана с идеями обновления, очищения и возрождения, что и определяет смысл символа [27, p. 46, 216].

6. Материал, техника изготовления.

6.1. Терминология. На сегодняшний день термин «египетский фаянс» [25, р. 326$328]$ является условным и означает искусственно приготовленное вещество, сформованное в основном из кварца (в форме микроосколков разбитых и растертых кварцевых галек или кварцевого песка) и природных соединений щелочных металлов (натрон или зола определенных растений). В смеси присутствует известь в форме песка или растертого известняка и природные пигменты (наиболее характерны минеральные агрегаты меди) ${ }^{6}$.

В начале I тыс. до н. э. техника изготовления египетского фаянса широко распространяется из Египта в Средиземноморье и на Ближний Восток [40, p. 312, 318]. При этом для получения конечного продукта применялись различные рецепты изготовления глазури и способы ее нанесения [34, p. 3].

Схема изготовления фаянсовых амулетов подробно описана А. Лукасом [2, с. 140-
143]. Основа фаянсового объекта формовалась из измельченного до пудры кварца. Связующей массой, придающей основе (сердцевине) пластичность, являлся водный раствор из щелочей и извести ${ }^{7}$. Пластичной пасте в форме придавали основные черты будущего изделия. Паста обладала тиксотропностью, после высыхания заготовки детали рельефа на них (изображения иероглифов, линейная штриховка и т. д.) часто сглаживались, поэтому важная роль перед обжигом отводилась абразивной подработке поверхности. Отдельные детали орнамента вручную или механически подрабатывались при помощи инструментов с острым концом.

\section{2. Подвеска-амулет из Филиппов-}

ки. По визуальным определениям изделие имеет отчетливое двухслойное строение. Первый слой - искусственно приготовленная основа (сердцевина) визуально светлого охристого цвета. Она состоит из угловатых зерен кварца, которые сцементированы сильно деструктированным связующим. Второй поверхностный слой тонкий $(0,8-0,6$ мм) и представлен цветной стекловидной глазурью. Гамма глазури светлая, выдержана в зеленовато-голубом тоне, имитирующем цвет бирюзы. Для двусторонних изображений характерно четкое соответствие нюансов орнамента (наклона и кривизны линий, соблюдение параллельности в проработке штрихового рисунка бровей и нижнего выступа). По классификации А. Лукаса это типичный египетский фаянс [2, с. 92].

Изучение трасологии линий (наклон нанесения, кривизна, выдерживание оси вдавливания по длине и т. д.) позволяет предположить применение механической обработки при нанесении рисунка. До сих пор неизвестно, когда начал применяться в этой операции гончарный круг. С эпохи Птолемеев он широко использовался при производстве фаянса [34, p. 4]. Крупные объекты формовались по частям, перед глазурованием части собирались и оклеивались той же пастой, сквозное отверстие образовывалось при помощи медной проволоки, которую после обжига выдергивали [2, с. 142].

Многочисленные находки керамических форм для изготовления мелких фаянсовых объектов известны на территории Древнего Египта в Эль-Амарне, Кантире, Мемфисе, Фивах, Гуробе и в Навкратисе. Все найден- 
ные на территории Египта формы были односторонними [2, с. 142].

Большинство исследователей отмечает, что в птолемеевскую эпоху возрастает число амулетов и подвесок из египетского фаянса с двусторонним изображением [18, р. $63 ; 31$, p. $765 ; 38$, p. $127 ; 44$, p. 148]. Из-за отсутствия находок неизвестно, использовали ли при производстве древнего фаянса закрытые двусторонние формы. Поскольку основные операции по формованию и выведению деталей изображения при изготовлении фаянса производятся в холодном состоянии перед глазурованием и финальным обжигом, возможно, что двустороннее изображение получали, используя симметричные односторонние формы, и в изготовлении специальных двусторонних форм не было необходимости [34, p. 2].

Присутствие в проработке деталей изображений глаза следов механической обработки поверхности позволяет предположить, что амулет был изготовлен не позднее второй половины - последней трети IV в. до н. э.

\section{3. Подвески-амулеты из Нового}

Кумака. По результатам визуального обследования материал подвесок не соответствует типичному египетскому фаянсу, так как его фактура однородна, массивна и резко отличается от фаянса филипповского амулета. Она представлена плотной однородной стекловатой массой бирюзового цвета без облицовочного слоя глазури. На участках неизменной поверхности видно, что первоначально его поверхность обладала блеском. На лицевой поверхности одного амулета сохранились остатки глазурованного покрытия черного цвета, нанесенные поверх рельефно выделенной надбровной дуги. На лицевой поверхности второй подвески аналогичное покрытие расположено в районе глаза и имеет круглую форму. Первоначальное изображение имело облик, представленный на хорошо сохранившихся экземплярах-аналогах данного типа (рис. 2, 11-16).

По классификации Лукаса, это стекловидный фаянс (вариант Е), в материал основы которого добавлена толченая смесь глазури, что при обжиге повышает твердость и уменьшает хрупкость материала. Такой фаянс характерен для египетских фаянсовых изделий с эпохи XXVI династии, то есть с VII в. до н. э. [2, с. 142-146].
7. Анализ состава и структуры фаянса амулета из Филипповки.

7.1. Техники глазурования египетского фаянса. По последним данным выделены три разные техники глазурования, отличающиеся консистенцией глазури, способом ее нанесения и физико-химическими параметрами финального обжига [34, p. 4-7; 46, p. 124 , 126; 48, p. 93-94]:

- «аппликация» использовалась для изготовления изразцов, мозаики, посуды, ваз, скульптурных изображений и статуэток. Широко применялась в Египте с додинастического по Римский периоды, в поздней бронзе появляется в Средиземноморье [34, р. $5 ; 43$, p. 25,$26 ; 44$, p. 116, 118];

- «цементация» открыта при создании базы данных составов стекла и фаянса из раскопок города Кум в Иране, использовалась преимущественно для малых объектов (бусы, амулеты, кольца), установлена в египетских объектах Раннего - Среднего царства, позднее в Египте утеряна [34, p. 7]. На рубеже II-I тыс. до н. э. распространяется в Палестине, Сирии [32, p. 14, 20-23], Древнем Иране, где просуществовала до эпохи Сасанидов [31, p. 770, 772; 43 , р. 20-22, 24-26; 48, p. 94, 96]. В римское время появляется в западном и Центральном Средиземноморье [45, p. 118-129];

- эффлоресценция применялась для производства малых и больших объектов. В Египте использовалась с эпохи Древнего царства до римского времени [34, p. 6], с эпохи Птолемеев широко распространяется в Средиземноморье и Малой Азии, где установлены экспонаты, выполненные в смешанной технике глазурования (аппликация-эффлоренция) [44, p. $102-110 ; 45$, p. $132-134 ; 46$, p. 136, 137].

7.2. Результаты исследования ${ }^{6}$. На микрофотографии (рис. $4, A$ ) отчетливо видно двухслойное строение глазурованного покрытия, представленного кварцевым стеклом (темно-серая зернистая масса) и собственно глазурью (белый цвет). Слой кварцевого стекла (серый цвет) является промежуточным между основой и глазурью и переходит в белый слой бескварцевой поверхностной глазури (серовато-белый и белый цвет). Границы между ними извилистые, что свидетельствует о проникновении глазури в матрикс сердцевины при финальном обжиге и преобразовании зернистой 
пористой поверхности основы в кварцевое стекло, окрашенное глазурью в бирюзовый цвет.

Гетеробластовая структура основы (рис. 4 ,

$B)$ представлена плотными микроагрегатами халцедона с микротрещинами и порами (темносерый цвет), заполненными кварцевым стеклом (белый и серый цвет). Преобладают мелкие угловатые зерна кварца оскольчатой формы, зерна кварца средней размерности единичны. В мелкой фракции присутствуют единичные зерна полевых шпатов и плагиоклазов альбитового состава (до 0,2 мм).

Таким образом, при финальном обжиге фаянса происходит укрепление пористой зернистой основы за счет глазурованного слоя благодаря образованию нового промежуточного слоя кварцевого микропористого стекла, являющегося составным новообразованным слоем глазури и за счет химических реакций плотно «сваривающего» глазурованное покрытие с кварцевой основой. Очевидно, этим объясняется хорошая сохранность глазурованного бирюзового покрытия амулета из Филипповки. Сравнительный анализ полученных результатов с опубликованными литературными данными по строению и составу археологических объектов из фаянса, выполненных в технике «цементации» [31, p. 765,770 , fig. 8,9 ; 43 , p. $21,24-26$, fig. 7,8 ; 44, p. 112, 118, fig. 7-8, 14-16; 45, p. 132, fig. 3], позволяет уверенно говорить, что изученный амулет был изготовлен именно в этой технике. Поскольку проведенный выше анализ пространственного проявления ареалов находок в данной технике глазурования показывает, что в I тыс. до н. э. техника «цементации» широко распространяется в Малой Азии и Древнем Иране, нельзя исключить, что данный амулет был изготовлен в мастерских Ахеменидского Ирана.

8. Заключение. На Южном Урале известны три подвески в виде глаза Хора. Все они происходят из курганных захоронений ранних кочевников и датируются по местным хронологическим шкалам V-IV вв. до н. э.

Один из амулетов (могильник Филипповка 1) происходит из закрытого археологического комплекса и лежал под зеркалом. Подробный анализ иконографии опубликованных на сегодняшний день датированных египетских аналогов этому амулету показывает, что двустороннее изображение Уаджет оформляется в фаянсе к середине II тыс. до н. э. Иконографические аналоги таких фаянсовых амулетов широко распространены в Египте в VIIIV вв. до н. э. (рис. 2, 1-14) и существуют до конца птолемеевского периода (рис. 2, 16). Наличие на филипповском амулете характерного валика для подвешивания, расположенного в центре верхней боковой грани, позволяет сузить дату его изготовления до 380 332 гг. до н. э.

Иконография амулета из Филипповки отличается отчетливо выраженным наклоном глаза вниз, что приводит к искажению пропорций, характерных для египетских амулетов. То есть при полной идентичности основных иконографических характеристик контур формы и пропорции филипповского амулета отличаются от египетских амулетов. Найти идентичные аналоги среди фаянсовых амулетов нам не удалось, однако среди золотых литых амулетов Уаджет характерный наклон глаза в амулетах этой формы появляется в моделях, украшенных в традициях древнеиранской ювелирной школы.

Датированные египетские аналоги амулетам из Нового Кумака показывают, что эта форма амулета зародилась в Египте в I Переходный период, ее характерный облик сформировался в период Нового царства и плавно трансформировался в Эллинистический и Римский периоды.

Анализ характера распространения египетских амулетов Уаджет в Средиземноморье показывает, что в результате перераспределения торговых сфер влияния в Центральном Средиземноморье в конце VII - начале VI в. до н. э. Уаджет-амулеты появляются в Восточном Средиземноморье. C VI в. до н. э. в торговле Средиземноморья с Ахеменидским Ираном возрастает посредническая роль греческих поселений, откуда амулеты Уаджет по «царской дороге», проходившей от Эфеса на Сарды и Сузы через Малую Азию, Армению и Ассирию и Древний Иран, распространяются далее на восток.

В нанесении и проработке деталей и линий рисунка амулета из Филипповки 1 установлено использование как ручной техники, так и применение механического станка. Известно, что для механической обработки по- 


\section{МЕЖДИСЦИПЛИНАРНЫЕ ИССЛЕДОВАНИЯ}

верхности фаянса гончарный круг широко использовался с птолемеевской эпохи. Это позволяет предположить, что амулет был изготовлен не ранее второй половины - последней трети IV в. до н. э.

Анализ изучения микроструктур и состава египетского фаянса амулета из Филипповки показывает, что процесс глазурования производился в технике «цементации». Микроструктуры глазурованного покрытия амулета из Филипповки наиболее близки глазурованному покрытию иранских фаянсовых бус, изготовленных в технике Кум (Qom technique) [43, p. 20-26]. Этот факт, наряду с проведенным выше анализом пространственного проявления ареалов находок, выполненных в технике «цементации», позволяет предположить, что данный амулет вполне мог быть изготовлен в мастерских Ахеменидского Ирана.

Изучение контуров формы и пропорций трех уральских амулетов (рис. $1,1 a, 3 b)$ показывает, что для их отливки использовались практически одинаковые формы, отличающиеся только положением сквозного отверстия. Следовательно, несмотря на то, что они сделаны из разных типов фаянса, отливаться могли в одном ремесленном центре.

Формирование иконографии амулетов в форме глаза Хора происходило в период Нового царства и отождествлялось с образом космического (небесного) Ока, которое контролировало справедливость земных законов, гармонию и благоденствие и устраняло хаос. При этом правое око Ра олицетворяло божественную природу фараона и справедливости его власти, а левый глаз Хора помогал обновлению и воскресению в загробном мире и являлся символом вечной жизни.

В древнем Египте амулеты широко использовались в погребальных жертвоприношениях и ритуалах для смягчения и ублажения богов, помогали воскресению и воплощению в загробном мире. Место таких культовых предметов было четко обозначено: прорези на личинах статуй, масок и антропоморфных гробов, положение их на лоб и грудь в одеждах мумий в гробницах.

Наличие таких амулетов в кочевнических погребениях Южного Урала и определенное местоположение амулета из Филипповки 1 в комплексе под зеркалом свидетельствует, что кочевники, безусловно, ассоциировали их с погребальным культом. Однако сложная семантика этого образа, характерная для Древнего Египта, ускользала от них или была трактована ими иначе.

Все три подвески входят в большую коллекцию находок ахеменидского круга, полученных с территории Южного Приуралья [8, c. 282-284].

\section{ПРИМЕЧАНИЯ}

${ }^{1}$ Известны нарисованные черной краской и вырезанные на каменных стенах усыпальниц и саркофагов Древнего царства изображения глаза Хора, линейный рисунок которых соответствует изображению на филипповской подвеске [15, S. 16]. Кроме того, в Среднем царстве отдельные части данного конкретного изображения глаза Хора использовались в арифметике для написания дробей от $1 / 2$ до ${ }_{64}[36$, p. 82,84$]$.

${ }^{2}$ В книге К. Эндрюс «Амулеты Древнего Египта» опубликована подвеска из египетского фаянса из коллекции музея искусств «Метрополитен», близкая по декору филипповской подвеске и датированная автором 1600-1100 гг. до н.э. [14, p. 182].

${ }^{3}$ Сайт Бостонского музея: http://www.mfa. org/collections/object/eye-of-horus-wedjat-amulet (дата обращения: 14.02.2018).

${ }^{4}$ В коллекции Бостонского музея изящных искусств есть подвеска (рис. 2,18 ) из раскопок Навкратиса, датированная концом Древнего царства I Переходным периодом 2323-2050 гг. до н. э. Это самый ранний датированный аналог новокумакским амулетам, найденный нами.

5 Два фаянсовых египетских амулета, иконография которых близка амулету из Филипповки 1 , найдены в погребениях VI в. до н. э. в Мингечауре [5, с. 21].

${ }^{6}$ Средний состав «фаянса» представлен кремнеземом $\left(\mathrm{SiO}_{2}\right)-92-99 \%$, известью $(\mathrm{CaO})-1-$ $5 \%$, «содой» $\left(\mathrm{Na}_{2} \mathrm{O}\right)$, с незначительной примесью меди $(\mathrm{CuO})$, магния $(\mathrm{MgO})$, калия $\left(\mathrm{K}_{2} \mathrm{O}\right)$, алюминия $\left(\mathrm{Al}_{2} \mathrm{O}_{3}\right)$ и следов других элементов [46, p. 124, 126].

7 Выполнены методами растровой электронной микроскопии (РЭМ) и рентгеноспектрального микроанализа (РСМА) с использованием микроскопа с термополевой эмиссией Supra 50VP (Carl Zeiss, Германия) и энергодисперсионного спектрометра INCA Energy+ (Oxford Instruments, Англия) в лаборатории факультета наук о материалах (ФНМ) МГУ им. М.И. Ломоносова науч. сотр., канд. хим. наук А.В. Гаршевым, которому авторы выражают глубокую благодарность. 


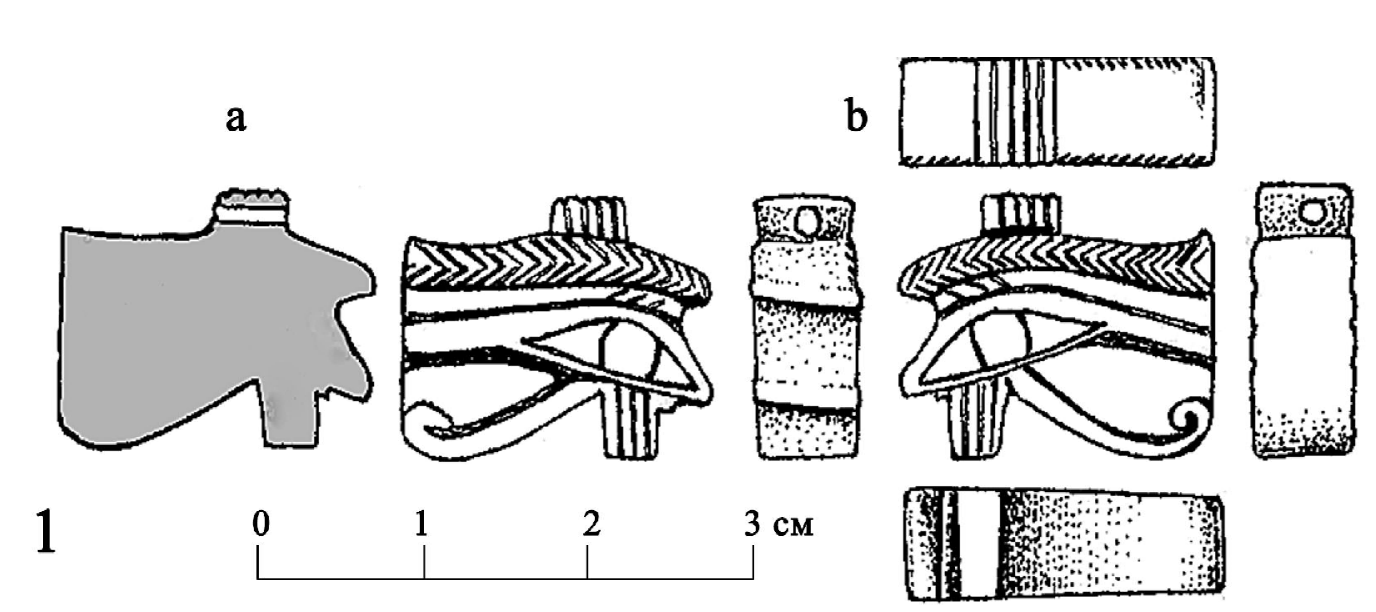

b
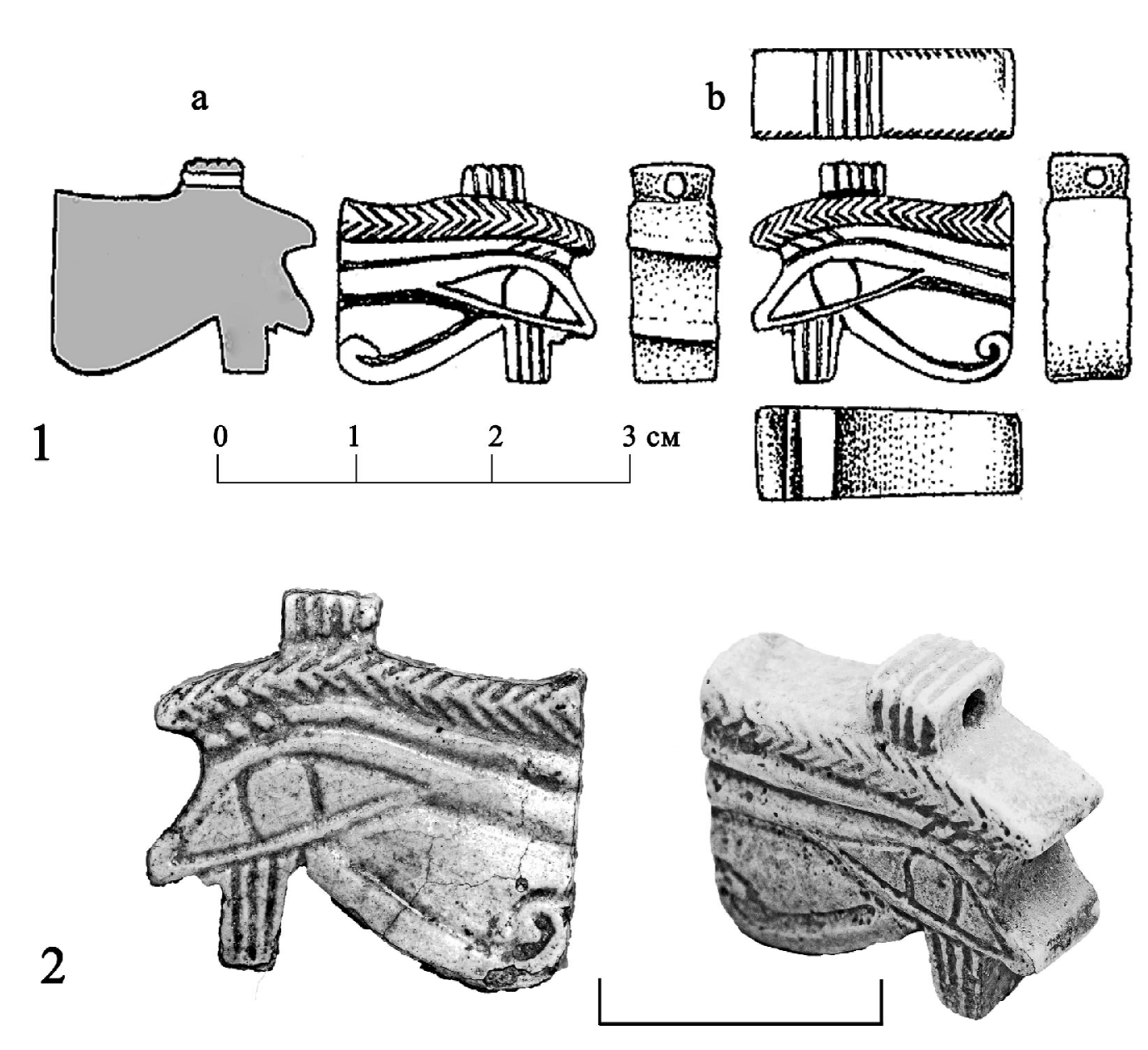

$\equiv$

a

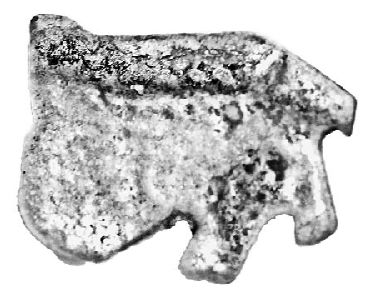

3
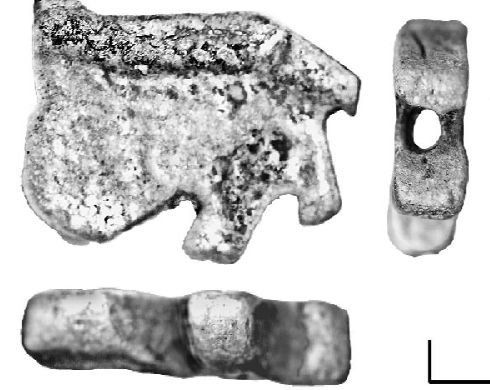
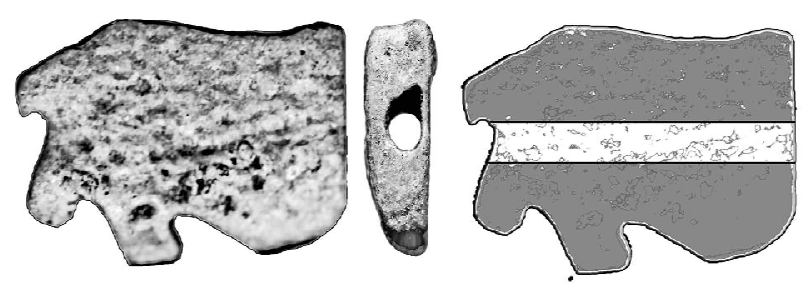

b

Рис. 1. Подвески-амулеты Уаджет (Глаз Хора), найденные в курганах ранних кочевников Южного Урала:

$1 a, 1 b, 2$ - продольный разрез, рисунок и фото амулета из могильника Филипповка 1 , курган 1 , погребение 2 ;

$3 a, 3 b$ - фото и продольный разрез амулета из могильника Новый Кумак, курган 26, погребение 2

Fig. 1. Wedjat (Eye of Horus) amulet-pendants from the mounds of early nomads of the Southern Urals:

$1 a, 1 b, 2$ - a longitudinal sectional view, drawing and photograph of an amulet from the Filippovka I burial mound, mound 1, burial 2; $3 a, 3 b$ - a photograph and longitudinal section of an amulet from the Novy Kumak burial mound, mound 26, burial 2 


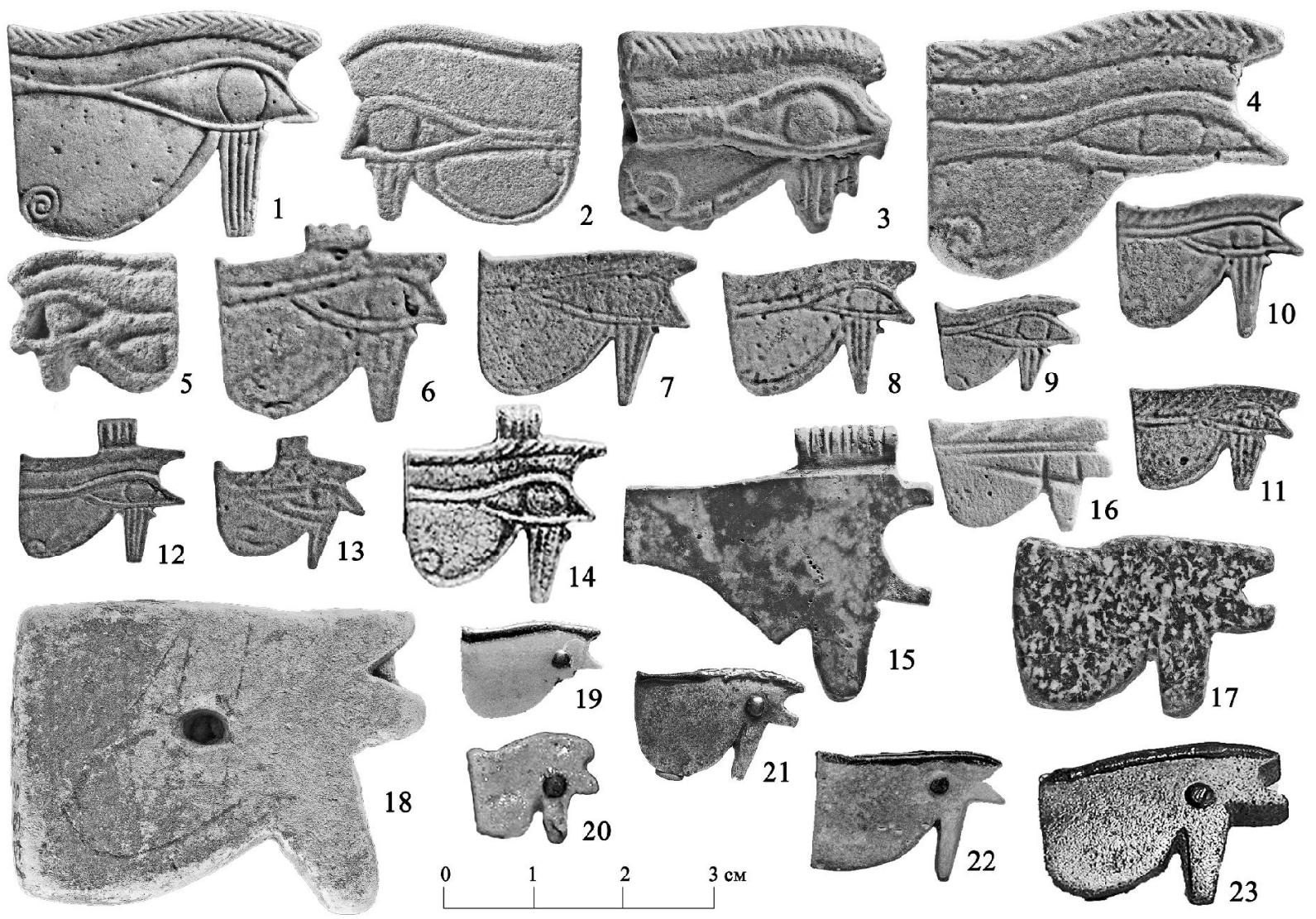

Рис. 2. Аналоги приуральским амулетам Уаджет в коллекциях:

1-13, 15-20 - Бостонский музей изящных искусств (http://www.mfa.org/collections/object/eye-of-horus-wedjat-amulet (дата обращения: 14.12.2017)); 14 - музей искусств «Метрополитен»; 21-22 - Британский музей; 23 - музей Университета в Сан-Франциско.

1 - Гиза, Египет (раскопки Гарвардского университета, 1930 г.), XXVI династия, 664-525 гг. до н. э., № 30-1-76 (http://www.mfa.org/collections/object/eye-of-horus-wedjat-amulet-409823);

2 - Танис, Египет (раскопки В.Ф. Питри, 1884 г.), Поздний период, 664-332 гг. до н. э., № 85.595 (http://www.mfa.org/collections/object/eye-of-horus-wedjat-amulet-130514);

3 - Танис, Египет (раскопки В.Ф. Питри, 1884 г.), Поздний период, 688-332 гг. до н. э., № 85.602 (http://www.mfa.org/collections/object/eye-of-horus-wedjat-amulet-131078);

4 - Навкратис, Египет (раскопки В.Ф. Питри, 1885 г.), Поздний период, 688-332 гг. до н. э., № 86.805 (http://www.mfa.org/collections/object/eye-of-horus-wedjat-amulet-133322);

5 - Танис, Египет (раскопки В.Ф. Питри, 1884 г.), Поздний период, 664-332 гг. до н. э., № 85.591 (http://www.mfa.org/collections/object/eye-of-horus-wedjat-amulet-130518);

6 - Танис, Египет (раскопки В.Ф. Питри, 1884 г.), XXX династия, 380-332 гг. до н. э., № 85.557 (http://www.mfa.org/collections/object/eye-of-horus-wedjat-amulet-130842);

7 - Танис, Египет (раскопки В.Ф. Питри, 1884 г.), XXX династия, 380-332 гг. до н. э., № 85.562 (http://www.mfa.org/collections/object/eye-of-horus-wedjat-amulet-130617);

8 - Танис, Египет (раскопки В.Ф. Питри, 1884 г.), XXX династия, 380-332 гг. до н. э., № 85.560 (http://www.mfa.org/collections/object/eye-of-horus-wedjat-amulet-130845);

9 - Танис, Египет (раскопки В.Ф. Питри, 1884 г.), XXX династия, 380-332 гг. до н. э., № 85.563 (http://www.mfa.org/collections/object/eye-of-horus-wedjat-amulet-130618);

10 - Танис, Египет (раскопки В.Ф. Питри, 1884 г.), XXX династия, 380-332 гг. до н. э., № 85.558 (http://www.mfa.org/collections/object/eye-of-horus-wedjat-amulet-130843);

11 - Танис, Египет (раскопки В.Ф. Питри, 1884 г.), XXX династия, 380-332 гг. до н. э., № 85.564 (http://www.mfa.org/collections/object/eye-of-horus-wedjat-amulet-130619);

12 - Танис, Египет (раскопки В.Ф. Питри, 1884 г.), XXX династия, 380-332 гг. до н. э., № 85.559 (http://www.mfa.org/collections/object/eye-of-horus-wedjat-amulet-130844);

13 - Танис, Египет (раскопки В.Ф. Питри, 1884 г.), XXX династия, 380-332 гг. до н. э., № 85.561 (http://www.mfa.org/collections/object/eye-of-horus-wedjat-amulet-130846);

14 - Египет, предположительно Поздний период, VI-IV вв. до н. э., № 89.2.415

(http://www.metmuseum.org/blogs/now-at-the-met/2015/nesmin (дата обращения: 12.06.2016)); 
15 - Танис, Египет (раскопки В.Ф. Питри, 1884 г.), Эллинистический период, 332-30 гг. до н. э., № 85.626 (http://www.mfa.org/collections/object/eye-of-horus-wedjat-amulet-131110);

16 - Танис, Египет (раскопки В.Ф. Питри, 1884 г.), Эллинистический период, 332-30 гг. до н. э., № 85.579;

17 - Навкратис, Египет (раскопки В.Ф. Питри, 1885 г.), конец Древнего царства - Эллинистический период,

2323-30 гг. до н. э., № 86.187 (http://www.mfa.org/collections/object/eye-of-horus-wedjat-amulet-131084);

18 - Навкратис, Египет (раскопки В.Ф. Питри, 1885 г.), конец Древнего царства - I Переходный период

2323-2050 гг. до н. э., № 86.186 (http://www.mfa.org/collections/object/eye-of-horus-wedjat-amulet-131085);

19 -Египет, предположительно конец Нового царства, XII-XI вв. до н. э., № 02.547

(http://www.mfa.org/collections/object/eye-of-horus-wedjat-amulet-130247);

20 - Египет, предположительно Поздний период, № 02.255

(http://www.mfa.org/collections/object/eye-of-horus-wedjat-amulet-133255);

21, 22 - Новое царство, 1550-1069 гг. до н. э., № 7326, 7328 (https://cowofgold.wikispaces.com/Eye+of+Horus (дата обращения: 12.06.2016));

23 - предположительно Тибет, № 219830 (https:/diva.sfsu.edu/collections/sfsum/bundle (дата обращения: 05.06.2016))

Fig. 2. Analogs of the southern Urals Wedjat amulets from the museum collections:

1-13, 15-20 - Boston Museum of Fine Arts, http://www.mfa.org/collections/object/eye-of-horus-wedjat-amulet

(accessed 14 December 2017); 14 - Metropolitan Museum of Art; 21-22 - British Museum;

23 - Museum of San Francisco University.

1 - Giza, Egypt (excavated by the Harvard University, 1930), $26^{\text {th }}$ dynasty, 664-525 BC, no. 30-1-76. http://www.mfa.org/collections/object/eye-of-horus-wedjat-amulet-409823;

2 - Tanis, Egypt (excavated by W.F. Petrie, 1884), The Late Period, 664-332 BC, no. 85.595. http://www.mfa.org/collections/object/eye-of-horus-wedjat-amulet-130514;

3 - Tanis, Egypt (excavated by W.F. Petrie, 1884), The Late Period, 688-332 BC, no. 85.602. http://www.mfa.org/collections/object/eye-of-horus-wedjat-amulet-131078;

4 - Naukratis, Egypt (excavated by W.F. Petrie, 1885), The Late Period, 688-332 BC, no. 86.805. http://www.mfa.org/collections/object/eye-of-horus-wedjat-amulet-133322;

5 - Tanis, Egypt (excavated by W.F. Petrie, 1884), The Late Period, 664-332 BC, no. 85.591. http://www.mfa.org/collections/object/eye-of-horus-wedjat-amulet-130518;

6 - Tanis, Egypt (excavated by W.F. Petrie, 1884), 30 ${ }^{\text {th }}$ dynasty, 380-332 BC, no. 85.557 . http://www.mfa.org/collections/object/eye-of-horus-wedjat-amulet-130842;

7 - Tanis, Egypt (excavated by W.F. Petrie, 1884), 30 ${ }^{\text {th }}$ dynasty, 380-332 BC, no. 85.562. http://www.mfa.org/collections/object/eye-of-horus-wedjat-amulet-130617;

8 - Tanis, Egypt (excavated by W.F. Petrie, 1884), 30 ${ }^{\text {th }}$ dynasty, 380-332 BC, no. 85.560 . http://www.mfa.org/collections/object/eye-of-horus-wedjat-amulet-130845;

9 - Tanis, Egypt (excavated by W.F. Petrie, 1884), 30 ${ }^{\text {th }}$ dynasty, 380-332 BC, no. 85.563. http://www.mfa.org/collections/object/eye-of-horus-wedjat-amulet-130618;

10 - Tanis, Egypt (excavated by W.F. Petrie, 1884), 30 ${ }^{\text {th }}$ dynasty, 380-332 BC, no. 85.558. http://www.mfa.org/collections/object/eye-of-horus-wedjat-amulet-130843;

11 - Tanis, Egypt (excavated by W.F. Petrie, 1884), 30 ${ }^{\text {th }}$ dynasty, 380-332 BC, no. 85.564. http://www.mfa.org/collections/object/eye-of-horus-wedjat-amulet-130619;

12 - Tanis, Egypt (excavated by W.F. Petrie, 1884), 30 ${ }^{\text {th }}$ dynasty, 380-332 BC, no. 85.559. http://www.mfa.org/collections/object/eye-of-horus-wedjat-amulet-130844;

13 - Tanis, Egypt (excavated by W.F. Petrie, 1884), 30 $0^{\text {th }}$ dynasty, 380-332 BC, no. 85.561. http://www.mfa.org/collections/object/eye-of-horus-wedjat-amulet-130846; 14 - Egypt, probably The Late Period, the $6^{\text {th }}-4^{\text {th }}$ centuries BC, no. 89.2.415.

http://www.metmuseum.org/blogs/now-at-the-met/2015/nesmin. (accessed 12 June 2016);

15 - Tanis, Egypt (excavated by W.F. Petrie, 1884), The Ptolemaic Kingdom, 332-30 BC, no. 85.626. http://www.mfa.org/collections/object/eye-of-horus-wedjat-amulet-131110;

16 - Tanis, Egypt (excavated by W.F. Petrie, 1884), The Ptolemaic Kingdom, 332-30 BC, no. 85.579;

17 - Naukratis, Egypt (excavated by W.F. Petrie, 1885), end of The Old Kingdom - the Hellenistic period,

2323-30 BC, no. 86.187. http://www.mfa.org/collections/object/eye-of-horus-wedjat-amulet-131084;

18 - Naukratis, Egypt (excavated by W.F. Petrie, 1885), end of The Old Kingdom - The First Intermediate Period,

2323-2050 BC, no. 86.186. http://www.mfa.org/collections/object/eye-of-horus-wedjat-amulet-131085;

19 - Egypt, probably the end of The New Kingdom, $12^{\text {th }}-11^{\text {th }}$ centuries BC, no. 02.547. http://www.mfa.org/collections/object/eye-of-horus-wedjat-amulet-130247;

20 - Egypt, probably The Late Period, no. 02.255. http://www.mfa.org/collections/object/eye-of-horus-wedjat-amulet-133255; 21, 22 - The New Kingdom, 1550-1069 BC, no. 7326, 7328. https://cowofgold.wikispaces.com/Eye+of+Horus (accessed 12 June 2016);

23 - probably Tibet, no. 219830, https://diva.sfsu.edu/collections/sfsum/bundle (accessed 5 June 2016) 


\section{МЕЖДИСЦИПЛИНАРНЫЕ ИССЛЕДОВАНИЯ}

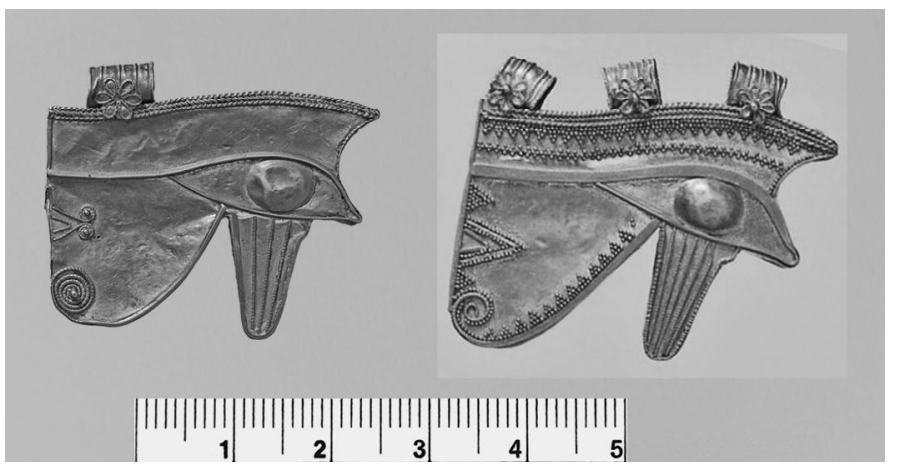

Рис. 3. Фотографии золотых амулетов Уаджет из коллекций музея искусств Метрополитен:

слева - Эллинистический период, 332-30 гг. до н. э., № 23.2.68; справа - Поздний период, 664-332 гг. до н. э., № 23.2.67 (http://www.metmuseum.org/art/collection/search/547767 (дата обращения: 14.12.2017))

Fig. 3. Photographs of golden Wedjat amulets from the collections of the Metropolitan Museum of Fine Art: on the left - The Ptolemaic Kingdom, 332-30 BC, no. 23.2.68; on the right - The Late Period, 664-332 BC, no. 23.2.67. http:/www.metmuseum.org/art/collection/search/547767 (accessed 14 December 2017) 
О.В. Аникеева, Л.Т. Яблонский. Амулеты «Глаз Хора» из курганов ранних кочевников на Южном Урале
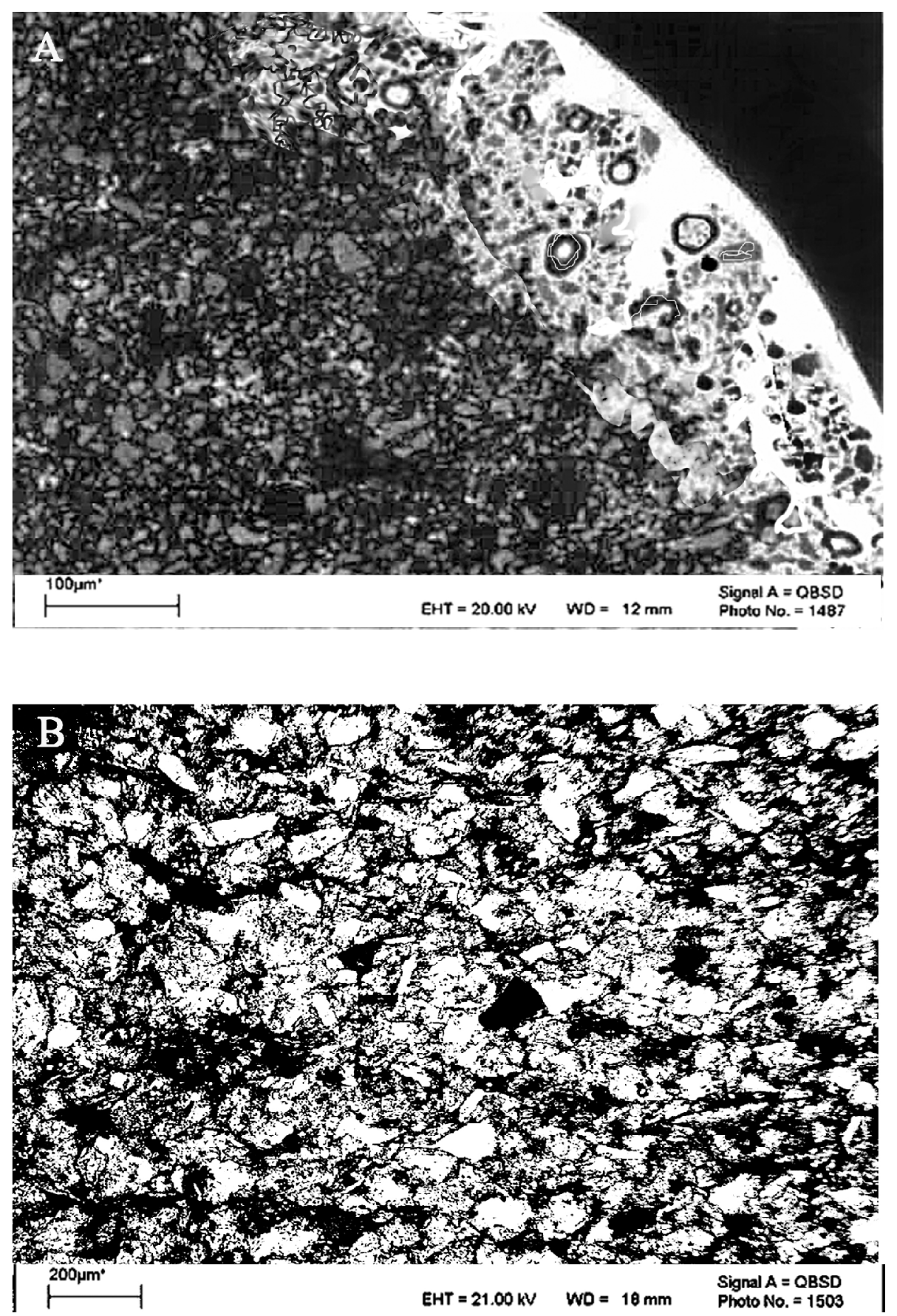

Рис. 4. Фотографии микроструктуры египетского фаянса амулета Уаджет из Филипповки 1, характеризующие его строение:

$A$ - структура основы и глазурованного покрытия; $B$ - гетеробластовая структура основы

Fig. 4. Photographs of the microstructure of the Egyptian faience of a Wedjat amulet from Filippovka I burial mound:

$A$ - the base and the glazed coating; $B$ - heteroblastic structure of the base 


\section{СПИСОК ЛИТЕРАТУРЫ}

1. Литвинский, Б. А. Зеркало в верованиях древних ферганцев / Б. А. Литвинский // СЭ. - 1964. № 3. - С. 97-104.

2. Лукас, А. Материалы и ремесленные производства древнего Египта / А. Лукас. - М. : Изд-во иностранной литературы, 1958. - 407 с.

3. Мошкова, М. Г. Сарматские погребения Ново-Кумакского могильника близ г. Орска / М. Г. Мошкова // Памятники Южного Приуралья и Западной Сибири сарматского времени. - М. : Наука, 1972. - С. 27-48. -(МИА ; № 153).

4. Пиотровский, Б. Б. Амулеты в форме глаза в Древнем Египте / Б. Б. Пиотровский // Известия Государственной Академии истории материальной культуры. - 1931. - Т. 9, вып. 3. - С. 6-24.

5. Пиотровский, Б. Б. Древнеегипетские предметы, найденные на территории Советского Союза / Б. Б. Пиотровский // СА. - 1958. - № 1. - С. 20-27.

6. Пшеничнюк, А. Х. Филипповка. Некрополь кочевой знати IV в. до н. э. на Южном Урале / А. Х. Пшеничнюк. - Уфа : Изд-во ИИЯЛИ УНЦ PAH, 2013. $-278 \mathrm{c}$.

7. Пяничук, О. Магическое значение амулетов в заупокойной практике Древнего Египта эпохи Среднего Царства / О. Пяничук // Актуальні проблеми вітчизняноі та всесвітньоі історіі: збірник наукових праць. - Харків : Харківський національний університет ім. В. Н. Каразіна, 2011. - № 4. - С. 38-45.

8. Трейстер, М. Ю. К вопросу об абсолютной дате могильника Филипповка I / М. Ю. Трейстер, Л. Т. Яблонский // Влияния ахеменидской культуры в Южном Приуралье (V-III вв. до н. э.) : в 2 т. M. : ТАУC, 2012. - T. I. - C. 282-284.

9. Хазанов, А. М. Религиозно-магическое понимание зеркал у сарматов / А. М. Хазанов // СЭ. 1963. - № 4. - С. 89-96.

10. Яблонский, Л. Т. Саки Южного Приаралья (археология и антропология могильников) / Л. Т. Яблонский. - М. : ТИМП, 1996. - 185 с.

11. Яблонский, Л. Т. Золото сарматских вождей. Элитный некрополь Филипповка 1 (по материалам раскопок 2004-2009 гг.). Каталог коллекции. Кн. 1 / Л. Т. Яблонский. - М. : ИА РАН, 2013. - $231 \mathrm{c}$.

12. Яблонский, Л. Т. Новые необыкновенные находки из кургана 1 могильника Филипповка 1 / Л. Т. Яблонский// АЭАЕ. -2015. - Т. 43, № 2. - С. 97-108.

13. Яблонский, Л.Т. Новые археологические данные об ахеменидских влияниях на Южном Урале / Л. Т. Яблонский // ВДИ. - 2016. - № 3. C. 744-766.

14. Andrews, C. Amulets of Ancient Egypt / C. Andrews. - London : British Museum Press, 1994. $-286 \mathrm{p}$.
15. Anthes, R. Das Sonnenauge in den Pyramidentexten / R. Anthes // ZÄS. - 1961. - Vol. 86. S. 1-21.

16. Ben-Ami, D. Miscellaneous small objects / A. Ben-Tor, A. Zarzecki-Peleg, Sh. Cohen-Anidjar // Yoqne'am II: The Iron Age and the Persian Period. Final Report of the Archaeological Excavations (19771988). Israel Exploration Society. Qedem Reports 6. Jerusalem : Institute of Archaeology, Hebrew University, 2005. - P. 377-394.

17. Cochrane, I. The Eye of Horus / I. Cochrane. P. 1-17. - Electronic text data. - Mode of access: http:// www.maverickscience.com/index.htm (date of access: 05.06.2016). - Title from screen.

18. Curtis, J. The Achaemenid Period in Northern Iraq / J. Curtis // Draft on "Colloque L'archéologie de l'empire achéménide". - Paris : Collège de France, 2003. -70 p.

19. Faulkner, R. O. The Bremner-Rhind Papyrus IV / R. O. Faulkner // Journal of Egyptian Archaeology. 1938. - Vol. 24. - P. 41-53.

20. Faulkner, R. O. The Ancient Egyptian Pyramid Texts / R. O. Faulkner. - London : Clarendon Press, 1969. $-330 \mathrm{p}$.

21. Faulkner, R. O. The Ancient Egyptian Book of the Dead / R. O. Faulkner. - University of Texas Press, 1990. - 192 p.

22. Faulkner, R. O. The Ancient Egyptian Coffin Texts / R. O. Faulkner. - Warminster : Aris \& Phillips, 2003. -800 p.

23. Faulkner, R. O. The Ancient Egyptian Pyramid Texts / R. O. Faulkner. - Montana : Kessinger Publishing, 2004. $-436 \mathrm{p}$.

24. Fletcher, R. Sidonians, Tyrians and Greeks in the Mediterranean: The Evidence from Egyptianising Amulets / R. Fletcher // Ancient West and East. 2004. - Vol. 3. - P. 51-77.

25. Griffin, P. S. Reconstructing the materials and technology of Egyptian faience and frit / P. B. Vandiver, M. Goodway, J. L. Massin // Materials issues in art and archaeology VI: Materials Research Society Symposium Proceedings. - Boston, Massachusetts : Materials Research Society 712, 2002. - P. 323-356.

26. Griffiths, G. J. Remarks on the Mythology of the Eyes of Horus / G. J. Griffiths // Croniqije d'Egypte. 1958. - Vol. 33, № 66. - P. 182-193.

27. Hornung, E. Exploring the Beyond / E. Hornung, B. M. Bryan // The Quest for Immortality: Treasures of Ancient Egypt. - New York : Prestel Publ., 2002. -288 p.

28. Istrati, C. I. Comunicarri archeologice / C. I. Istrati // Analele Academiei Romane. - Bucuresti, 1911-1912. - Bd. XXIV. - S. 129-138.

29. Johnson, S. B. The Cobra Goddess of Ancient Egypt / S. B. Johnson. - London : Kegan Paul, 1990. $276 \mathrm{p}$. 
30. Koc, B. The superstitious mystery behind the eye: the symbol of eye and the way that the evil eye bead is reflected in Turkish society from the ancient history to present / B. Koc, A. Temur // Journal of History School. - 2014. - Iss. XVIII. - P. 11-50.

31. Matin, M. Egyptian faience glazing by the cementation method part 1: an investigation of the glazing powder composition and glazing mechanism / M. Matin, M. Matin // Journal of Archaeological Science. - 2012. - Vol. 39, iss. 3. - P. 763-776.

32. McGovern, P. E. The Late Bronze Egyptian Garrison at Beth Shan: Glass and Faience Production and Importation in the Late New Kingdom / P. E. McGovern, S. J. Fleming, C. P. Swann // Bulletin of the American Schools of Oriental Research. - 1993. Iss. 290/291. - P. 1-27.

33. Muscarella, O. W. The Iron Age at Dinkha Tepe, Iran / O. W. Muscarella // Metropolitan Museum Journal. - 1974. - Vol. 9. - P. 35-90.

34. Nicholson, P. T. Faience Technology / P. T. Nicholson, Willeke Wendrich // UCLA Encyclopedia of Egyptology. - Los Angeles, 2003. P. 1-11. - Electronic text data. - Mode of access: http:// digita12.library.ucla.edu/viewItem.do? $\operatorname{ark}=21198$ / zz0017jtts (date of access: 14.02.2018). - Title from screen.

35. Petrie, F. Amulets. The Egyptian Collection in University College / F. Petrie. - London : University College, 1914. $-58 \mathrm{p}$.

36. Pinch, G. Magic in Ancient Egypt / G. Pinch. London : British museum press, 2006. - 96 p.

37. Quirke, S. AncientEgyptian Religion/S. Quirke. London : British museum press, 1992. - 492 p.

38. Rankine, D. HEKA. The Practices of Ancient Egyptian Ritual and Magic / D. Rankine. - London : Avalonia, 2006. - 196 p.

39. Rehm, E. Der schmuck der Achameniden. Altertumskunde des Vorderen Orients / E. Rehm. Munster : Ugarit-Verlag, 1992. - 256 S.

40. Shaw, I. The Oxford history of Ancient Egypt / I. Shaw. - New York : Oxford University Press, 2000. $544 \mathrm{p}$.

41. Simpson, W. K. The Literature of Ancient Egypt / W. K. Simpson. - London; New Haven : Yale University Press, 2003. -598 p.

42. Sparavigna, A. C. Ancient Egyptian Seals and Scarabs / A. C. Sparavigna. - Torino : Lulu.com, 2009. $52 \mathrm{p}$.

43. Tite, M. S. Egyptian faience: An investigation of the methods of production / M. S. Tite, I. C. Freestone, M. Bimson // Archaeometry. - 1983.Vol. 25, iss. 1. - P. 17-27.

44. Tite, M. Production technology of faience and related vitreous materials / M. Tite, A. Shortland. Oxford : Oxford University School of Archaeology, 2008. $-232 \mathrm{p}$.
45. Vandiver, P. Appendix A: The manufacture of faience / P. Vandiver // Kaczmarczyk A., Hedges R.E.M. Ancient Egyptian faience: An analytical survey of Egyptian faience from Predynastic to Roman times. - Warminster : Cambridge University Press, 1983. - P. 1-143.

46. Vandiver, P. A review and proposal of new criteria for production technologies of Egyptian faience / P. Vandiver // Colin-art S., Menu M. La couleur dans la peinture et l'émaillage de l'Égypte ancienne: Actes de la table ronde, Ravello. - Bari : Edipuglia, 1998. - P. 121-139.

47. Wilson, J. J. Deliverance of Mankind from Destruction / J. J. Wilson // Pritchard, J. The Ancient Near Eastern Texts. - New Jersey: Princeton University Press, 1958. - $710 \mathrm{p}$.

48. Yamahana, K. Synchrotron Radiation Analysis on Ancient Egyptian Vitreous Materials / K. Yamahana // Proceedings of the 25th Linear Accelerator Meeting in Japan. - Himeji, 2000. - P. 92-96.

\section{REFERENCES}

1. Litvinskiy B.A. Zerkalo v verovaniyakh drevnikh fergantsev [The Mirror in the Ancient Fergana People's Religious Beliefs]. Sovetskaya etnografiya [Soviet Ethnography], 1964, iss. 3, pp. 97-104.

2. Lukas A. Materialy $i$ remeslennye proizvodstva drevnego Egipta [Materials and Industries of Ancient Egyptian]. Moscow, Izd-vo inostrannoy lit-ry, 1958. $407 \mathrm{p}$.

3. Moshkova M.G. Sarmatskie pogrebeniya Novo-Kumakskogo mogilnika bliz g. Orska [Sarmatian Burials of the Novo-Kumak Burial Near near the City of Orsk]. Pamyatniki Yuzhnogo Priuralya i Zapadnoy Sibiri sarmatskogo vremeni [Sarmatian Archaeological Sites of the Southern Cis-Urals and West Siberia]. Moscow, Nauka Publ., 1972, iss. 153, pp. 27-48.

4. Piotrovskiy B.B. Amulety $v$ forme glaza $v$ Drevnem Egipte [Amulets in the Form of Eye in Acient Egypt]. Izvestiya Gosudarstvennoy Akademii istorii materialnoy kultury. Saint Petersburg, 1931, vol. 9, iss. 3, pp. 6-24.

5. Piotrovskiy B.B. Drevneegipetskie predmety, naydennye na territorii Sovetskogo Soyuza [Ansient Egypt Items found in the Soviet Union Territory]. Sovetskaya arkheologiya [Soviet Archaeology], 1958, iss. 1, pp. 20-27.

6. Pshenichnyuk A.Kh. Filippovka. Nekropol kochevoy znati IV v. do n.e. na Yuzhnom Urale [Filippovka. The Necropolis of the Nomadic Nobility of the $4^{\text {th }} \mathrm{c}$. BC in the Southern Urals]. Ufa, Izd-vo IIYaLI UNTs RAN, 2013. 278 p.

7. Pyanichuk O. Magicheskoe znachenie amuletov v zaupokoynoy praktike Drevnego Egipta epokhi Srednego Tsarstva [Magical amulets in the 
value of the funeral practices of ancient Egypt of the Middle Kingdom]. Aktualni problemi vitchiznyanoi ta vsesvitnoi istorii: zbirnik naukovikh prats. Kharkiv, Kharkivskiy natsionalniy universitet im. V.N. Karazina, 2011, iss. 14, pp. 38-45.

8. Treyster M.Yu., Yablonskiy L.T. K voprosu ob absolyutnoy date mogilnika Filippovka-I [On Precise Dating of the Filippovka I Burial Mound]. Vliyaniya akhemenidskoy kultury $v$ Yuzhnom Priuralye ( $V-I I I v v$. do n.e.): $v 2 t$. [Influences of the Achaemenid Culture in the Southern Cis-Urals (the $5^{\text {th }}-3^{\text {rd }}$ centuries BC)]. Moscow, TAUS Press, 2012, vol. 1, pp. 282-284.

9. Khazanov A.M. Religiozno-magicheskoe ponimanie zerkal u sarmatov [The Religious and Perception of the Mirrors by Sarmatians]. Sovetskaya etnografiya [Soviet Ethnography], 1963, iss. 4, pp. 89-96.

10. Yablonsky L.T. Saki Yuzhnogo Priaralya (arkheologiya i antropologiya mogilnikov) [The Saks of the South Aral Region (Archaeology and Anthropology of Burial Mounds]. Moscow, TIMP Press, 1996. 185 p.

11. Yablonsky L.T. Zoloto sarmatskikh vozhdey. Elitnyy nekropol Filippovka 1 (po materialam raskopok 2004-2009 gg.). Katalog kollektsii. Kniga 1 [The Gold of the Sarmatian Chifs. The Elite Necropolis Filippovka 1 (Based on the Materials of Excavations, 2004-2009). Catalogue of the Collection. Book 1]. Moscow, IA RAS Press, 2013. 231 p.

12. Yablonsky L.T. Novye neobyknovennye nakhodki iz kurgana 1 mogilnika Filippovka 1 [New Unusial Finds from Mound 1 of the Filippovka 1 Burial Mound]. Arkheologiya, etnografiya $i$ antropologiya Evrazii [Archaeology, Anthropology and Ethnography of Eurasia], 2015, vol. 43, iss. 2, pp. 97-108.

13. Yablonsky L.T. Novye arkheologicheskie dannye ob akhemenidskikh vliyaniyakh na Yuzhnom Urale [New Archaeological Data on Achaemenid Influences in the Southern Urals]. Vestnik Drevney Istorii [Journal of Ancient History], 2016, iss. 3, pp. 744-766.

14. Andrews C. Amulets of Ancient Egypt. London, British Museum Press, 1994. 286 p.

15. Anthes R. Das Sonnenauge in den Pyramidentexten. Z̈̈S, 1961, vol. 86, pp. 1-21.

16. Ben-Ami D. Miscellaneous small objects. BenTor A., Zarzecki-Peleg A., Cohen-Anidjar Sh., eds. Yoqne'am II: The Iron Age and the Persian Period. Final Report of the Archaeological Excavations (1977-1988). Israel Exploration Society. Qedem Reports 6. Jerusalem, Institute of Archaeology, Hebrew University, 2005, pp. 377-394.

17. Cochrane I. The Eye of Horus. 2013. URL: http: www.maverickscience.com/index.htm (accessed 5 June 2016).

18. Curtis J. The Achaemenid Period in Northern Iraq. Draft în "Colloque L'archéologie de l'empire achéménide. Paris, Collège de France, 2003. 70 p.
19. Faulkner R.O. The Bremner-Rhind Papyrus-IV. Journal of Egyptian Archaeology, 1938, vol. 24, pp. 41-53

20. Faulkner R.O. The Ancient Egyptian Pyramid Texts. London, Clarendon Press, 1969. 330 p.

21. Faulkner R.O. The Ancient Egyptian Book of the Dead. Reprint edition. University of Texas Press, 1990. 192 p.

22. Faulkner R.O. The Ancient Egyptian Coffin Texts. Warminster, Aris \& Phillips, 2003. 800 p.

23. Faulkner R.O. The Ancient Egyptian Pyramid Texts. Reprint edition. Montana, Kessinger Publishing, 2004. 436 p.

24. Fletcher R. Sidonians, Tyrians and Greeks in the Mediterranean: The Evidence from Egyptianising Amulets. Ancient West and East, 2004, vol. 3, pp. 51-77.

25. Griffin P.S. Reconstructing the materials and technology of Egyptian faience and frit. Vandiver P.B., Goodway M., Massin J.L., eds. Materials issues in art and archaeology VI: Materials Research Society Symposium Proceedings. Boston; Massachusetts, 2002, vol. 712, pp. 323-356.

26. Griffiths G.J. Remarks on the Mythology of the Eyes of Horus. Croniqije d'Egypte, 1958, vol. 33, no. $66, \mathrm{pp} .182-193$.

27. Hornung E., Bryan B.M. Exploring the Beyond. The Quest for Immortality: Treasures of Ancient Egypt. New York, Prestel Publ., 2002. 288 p.

28. Istrati C.I. Comunicarri archeologice. Analele Academiei Romane. Bucuresti, 1911-1912, vol. XXIV, pp. 129-138.

29. Johnson S.B. The Cobra Goddess of Ancient Egypt. London, Kegan Paul, 1990. 276 p.

30. Koc B., Temur A. The superstitious mystery behind the eye: the symbol of eye and the way that the evil eye bead is reflected in Turkish society from the ancient history to present. Journal of History School, 2014, iss. XVIII, pp. 11-50.

31. Matin M. Egyptian faience glazing by the cementation method part 1: an investigation of the glazing powder composition and glazing mechanism. Journal of Archaeological Science, 2012, vol. 39, iss. 3, pp. 763-776.

32. McGovern P.E., Fleming S.J., Swann C.P. The Late Bronze Egyptian Garrison at Beth Shan: Glass and Faience Production and Importation in the Late New Kingdom. Bulletin of the American Schools of Oriental Research, 1993, iss. 290/291, pp. 1-27.

33. Muscarella O.W. The Iron Age at Dinkha Tepe, Iran. Metropolitan Museum Journal, 1974, vol. 9, pp. 35-90.

34. Nicholson P.T. Faience Technology / Willeke Wendrich. UCLA Encyclopedia of Egyptology. Los Angeles, 2003, pp. 1-11. URL: http://digital2.library. ucla.edu/viewItem.do?ark=21198/zz0017jtts (accessed 14 February, 2018). 
35. Petrie F. Amulets. The Egyptian Collection in University College. London, University College, $1914.58 \mathrm{p}$.

36. Pinch G. Magic in Ancient Egypt. London, British museum press, 2006. $96 \mathrm{p}$.

37. Quirke S. Ancient Egyptian Religion. London, British museum press, 1992.492p.

38. Rankine D. HEKA. The Practices of Ancient Egyptian Ritual and Magic. London, Avalonia, 2006. 196 p.

39. Rehm E. Der schmuck der Achameniden. Altertumskunde des Vorderen Orients. Munster, Ugarit Verlag, 1992. 256 p.

40. Shaw I. The Oxford history of Ancient Egypt. New York, Oxford University Press, 2000. 544 p.

41. Simpson W.K. The Literature of Ancient Egypt. London; New Haven, Yale University Press, 2003. 598 p.

42. Sparavigna A.C. Ancient Egyptian Seals and Scarabs. Torino, Lulu.com, 2009. 52 p.

43. Tite M.S., Freestone I.C., Bimson M. Egyptian faience: An investigation of the methods of production. Archaeometry, 1983, vol. 25, iss. 1, pp. 17-27.

44. Tite M., Shortland A. Production technology of faience and related vitreous materials. Oxford, Oxford University School of Archaeology, 2008. 232 p.

45. Vandiver P. Appendix A: The manufacture of faience. Kaczmarczyk A., Hedges R.E.M. Ancient Egyptian faience: An analytical survey of Egyptian faience from Predynastic to Roman times. Warminster, Cambridge University Press, 1983, pp. 1-143.
46. Vandiver P. A review and proposal of new criteria for production technologies of Egyptian faience. Colin-art S., Menu M., eds. La couleur dans la peinture et l'émaillage de l'Égypte ancienne: Actes de la table ronde, Ravello. Bari, Edipuglia, 1998, pp. 121-139.

47. Wilson J.J. Deliverance of Mankind from Destruction. Pritchard J., ed. The Ancient Near Eastern Texts. New Jersey, Princeton University Press, 1958. $710 \mathrm{p}$.

48. Yamahana K. Synchrotron Radiation Analysis on Ancient Egyptian Vitreous Materials. Proceedings of the 25th Linear Accelerator Meeting in Japan. Himeji, 2000, pp. 92-96.

\section{СПИСОК СОКРАШЕНИЙ}

АЭАЕ - Археология, этнография и антропология Евразии.

СЭ-Советская этнография.

МИА - Материалы и исследования по археологии СССР.

СА - Советская археология.

ВДИ-Вестник древней истории.

ОРОМ - Оренбургский областной (губернаторский) историко-краеведческий музей.

ZÄS - Zeitschrift für Ägyptische Sprach.

APAW - Amelia Patrons for Animal Welfare .

UCLA - University of California, Los Angeles.

\section{Information about the Authors}

Olga V. Anikeeva, Candidate of Sciences (Geology and Mineralogy), Leading Researcher, Department of Monumental Sculpture, State Research Institute for Restoration, Gastello St., 44/1, 107014 Moscow, Russian Federation, olganikeeva@yandex.ru, https://orcid.org/0000-0002-8725-4171

Leonid T. Yablonsky, Doctor of Sciences (History), Professor, Head of Department of ScythianSarmatian Archaeology, Institute of Archaeology, Russian Academy of Sciences, Dmitriya Ulyanova St., 19, 117036 Moscow, Russian Federation.

\section{Информация об авторах}

Ольга Викторовна Аникеева, кандидат геолого-минералогических наук, ведущий научный сотрудник отдела монументальной скульптуры, Государственный научно-исследовательский институт реставрации, ул. Гастелло, 44/1, 107014 г. Москва, Российская Федерация, olganikeeva@yandex.ru, https://orcid.org/0000-0002-8725-4171

Леонид Теодорович Яблонский, доктор исторических наук, профессор, заведующий отделом скифо-сарматской археологии, Институт археологии РАН, ул. Дм. Ульянова, 19, 117036 г. Москва, Российская Федерация. 